\title{
AGAMA DJAWA SUNDA (ADS)
}

\author{
Roro Sri Rejeki Waluyajati \\ Jurusan Perbandingan Agama Fakultas Ushuluddin UIN Sunan Gunung Djati Bandung \\ Jl. A.H. Nasution 105 Cibiru, Bandung 40614, Indonesia. \\ E-mail: enci.roro@gmail.com
}

\begin{abstract}
The purpose of this article is to express the community about the existence of a indigenous religion whose existence nearly extinct. Indigenous religion is in known in the name of ADS (Religion Djawa Sunda). In expressing existence ADS and the use writers' research methodology kulaitatif by using data analysis is inductive. Location for research in doing in Cigugur Village, district Kuningan. The result showed that Religion Djawa Sunda (ADS) is a religion local trying to combine between the sunda wiwitan and Islamic teachings.
\end{abstract}

Keywor ds:

Indigenous religion; Cigugur; Sunda Wiwitan

\section{Abstrak}

Tujuan dari artikel ini adalah untuk mengungkapkan pada masyarakat tentang keberadaan sebuah agama asli yang keberadaannya hampir punah. Agama asli tersebut dikenal dengan nama ADS (Agama Djawa Sunda). Dalam mengungkapkan keberadaan ADS ini maka penulis menggunakan metode penelitian kualitatif dengan menggunakan analisis data bersifat induktif. Adapun lokasi penelitian di desa Cigugur Kabupaten Kuningan. Hasil penelitian menunjukkan bahwa Agama Djawa Sunda (ADS) adalah sebuah agama lokal yang mencoba menggabungkan antara ajaran Sunda Wiwitan dan ajaran Agama Islam.

Kata Kunci:

Agama asli; Cigugur; SundaWiwitan

\section{A. PENDAHULUAN}

Agama Djawa Sunda (ADS) atau yang biasa di kenal oleh masyarakat dengan ajaran Madrais, merupakan salah satu ajaran agama lokal yang mempunyai pengaruh cukup besar di tanah Jawa Barat ini, bermula dari sebuah desa di Cigugur Kabupaten Kuningan hingga meluas ke daerah Banten, Garut, Bandung dan Cirebon. Pengaruh ADS ini cukup penting bagi perkembangan agama lokal di Jawa Barat, hal itu dibuktikan dengan berdirinya satu kampung di daerah Cireunde, Cimahi Bandung yang menjadikan ADS sebagai rujukan dalam sistim kepercayaannya, walaupun pada pengaplikasiannya telah di modifikasi dan terasimiliasi dengan budaya setempat. Ajaran ADS mungkin sekarang tinggal kenangan di sebagian tempat, tetapi indikasi keberadaan pengikutnya masih banyak terdapat di tempat asalnya Cigugur kuningan.
Pada artikel kali ini penulis akan mengungkap secara gamblang tentang apa itu ADS, mulai dari asal usul pemunculan, ajarannya hingga perkembangan ajaran tersebut saat ini.

\section{B. HASIL DAN PEMBAHASAN \\ 1. Kondisi Geografis dan Sosial Keagamaan Masyarakat Cigugur Kuningan Jawa Barat ${ }^{1}$}

Cigugur adalah sebuah kecamatan di Kabupaten Kuningan Jawa Barat, letak kecamatan secara geografis berada di bawah kaki Gunung Ceremai dengan ketinggian 700 $\mathrm{m}$ di atas permukaan laut dengan curah hujan rata-rata $26,8 \mathrm{~mm}$ dan suhu udara rata-rata $26^{\circ}$ C. Adapun batas-batas wilayahnya sebagai berikut : sebelah utara sebelah timur Kecamatan Kuningan, Kecamatan Kramatmulya, sebelah selatan Kecamatan Kadugede, sebelah barat Gunung Ciremai. Untuk jumlah pen-

\footnotetext{
${ }^{1}$ http://id.wikipedia.org/wiki/Cigugur,_Kuningan\#Batas -batas_Wilayah
} 
duduk kecamatan 7.084 jiwa, untuk mata penceharian warga Cigugur kebanyakan sebagai petani. Tingkat pendidikan masyarakat kampung ini masih tergolong rendah, karena itu pemahaman keagamaannyapun masih bersifat pasif.

Tetapi untuk kondisi keagamaan masyarakat desa sebelah malah menganut aliran Islam fanatik, hingga terhadap masyarakat kampung Cigugur mereka kurang akur. Ketika mendakwahkan ajaran Islam mereka kurang sabar dan cepat menilai seseorang kafir. Itulah yang mengakibatkan ketika seorang yang bernama Madrais menciptakan ajaran baru yaitu ADS banyak dari masyarakat Cigugur Kuningan ini menyambutnya.

\section{Sejarah Kelahiran Agama Djawa Sunda}

Di ceritakan pada tahun 1848 di desa cigugur berdiri sebuah aliran kepercayaan yang dikenal dengan mana Agama Djawa Sunda atau di singkat ADS, pendirinya adalah Madrais menurut riwayat Madrais masih keturunan Sultan-sultan Cirebon, hal itu dikisahkan sebagai berikut:

Seorang Pangeran keturunan sultan di Cirebon mempunyai selir (istri yang dikawin sah tetapi di akui sebagai istri tidak resmi) di salah satu desa Kecamatan Losari Cirebon, ayah dari si selir tadi termasuk guru ngaji (guru agama Islam) dikampung. Dari selir itu lahir anak lakilaki yang diberi nama oleh kakeknya (ayah si selir) Muhammad Rais, yang akhirnya disebut orang-orang Madrais. Menurut cerita sang pangeran tadi tidak pernah datang-datang lagi sehingga tidak tahu kepada anaknya, juga sebaliknya. Yang di kira oleh Madrais ayahnya adalah kakeknya. Karena selang beberapa lama setelah mempunyai anak si ibupun meninggal dunia. Sampai dewasa Madrais memperoleh pendidikan agama dari kakeknya yang pengetahuan Islamnya tidak banyak. Semenjak dewasa Madrais sadar bahwa yang dianggap ayahnya adalah kakeknya selama ini, kemudian Madrais meminta izin pada kakeknya untuk menemui ayahnya atau saudara dari ayahnya di kota
Cirebon, disana ia tidak mendapat keterangan yang memuaskan, tetapi ia dapat tinggal sebagai pelayan pada salah seorang pangeran di Cirebon, karena patuh dan rajin, Madrais di sayang oleh induk semangnya, sehingga diberi pelajaran ngelmu Cirebon atau ngelmu sejati atau ngelmu hakikat. ${ }^{2}$

Sejak waktu itu pandangan orang mulai berubah, menganggap seolah-olah Madrais termasuk keluarga Sultan Cirebon, kemudian ia menikah dengan seorang perempuan yang berasal dari desa Cigugur kemudian iapun menetap disana dan mengembangkan ajarannya. Sudah menjadi rahasia umum bahwa orangorang yang mempelajari ngelmu Cirebon kalau tidak dibarengi dengan pengetahuan agama Islam yang baik, hasilnya orang tersebut akan melalaikan ajaran syariat Islam dan lebih mengutamakan ajaran ngelmu Cirebon. ${ }^{3}$ Begitupun yang terjadi pada Madrais. Pada perkembangan selanjutnya Madrais mencoba mengkolaborasikan ajaran Ngelmu sejati Cirebon dan menciptakan ajaran baru yang disebut ADS (Agama Djawa Sunda).

Mengapa di sebut Ajaran Djawa Sunda, karena ajaran ini mencoba mengkolaborasikan antara ngelmu sejati Cirebon yang identik dengan tradisi kejawen dengan tasauf Islam dan tradisi Sunda Wiwitan, hal ini bisa di pahami karena ADS muncul dan berkembang di Cigugur Kuningan, dan seperti yang kita ketahui bahwa Kuningan secara geografis terletak di daerah perbatasan Jawa Barat dan Jawa Tengah hingga budaya Jawa dan Sunda terasimilasi cukup kuat di daerah ini.

Sedangkan menurut versi lainnya Madrais sering disebut sebagai Pangeran Madrais Alibasa Widjaja Ningrat, yang di percaya sebagai keturunan sultan Gebang Pangeran Alibasa I, sedangkan menurut cucunya yang masih hidup pangeran Djatikusuma, Nama Madrais berasal dari Muhammad rais sebuah nama yang diberikan kakeknya.

\footnotetext{
${ }^{2}$ Prof. Kamil Kartapraja, Aliran Kebatinan dan kepercayaan Di Indonesia, CV Haji Masagung, Jakarta, 1990. hlm 131.

${ }^{3}$ Ibid. hlm 131
} 
Dikisahkan pada usia 10-13 tahun ia tinggal di pesantren, namun terpaksa ditunda karena menerima bisikan gaib yang memberi petunjuk agar ia pergi, menelusuri dusun-dusun baik besar ataupun kecil yang biasanya dituju adalah tempat-tempat yang dikenal secara umum sebagai tempattempat angker yang digunakan sebagai tempat-tempat pemujaan, kemudian ditempat itulah ia bertapa. Dengan maksud untuk mencari rahasia semesta alam baik lahir maupun batin. ${ }^{4}$

Dari pengembaraanya inilah Madrais mengembangkan ajaran ADS, untuk sebagaian orang ADS dianggap sebagai gabungan dari ajaran tasawuf Islam dengan mistisme Jawa yang dibingkai dengan unsur-unsur kebudayaan Sunda. Dari Cigugur, ADS berkembang ke pelosok Jawa Barat seperti Indramayu, Majalengka, Ciamis, Tasikmalaya, Garut, Bandung, Padalarang, Bogor, Purwakarta, bahkan sampai DKI Jakarta. Jumlah penganut ADS dipercaya pernah mencapai lebih dari 100.000 orang, namun yang tercatat dalam buku cacah jiwa hanya sekitar 25.000 orang.

\section{Istilah-istilah Keagamaan Dalam Ajaran Agama Djawa Sunda ${ }^{5}$}

1. Syahadat agama Djawa Sunda dalam bahasa sunda yang artinya: tidak Ada tuhan melainkan Allah dan Madrais ialah Rosullah. Rosullah menurut ajaran Madrais bukan berarti utusan Allah, tetapi Rosulullah artinya rasa sejati. Madrais artinya bukan nama orang tetapi hakikat dari nama tersebut ialah cahaya sejati.

2. Kupasan dari kejadian manusia berasal dari api, air, angin dan tanah. Yang dipandang sumber dari segala kejadian menurut ajaran Madrais ialah api, oleh karena itu Madrais memuliakan api sejati, yang tidak tampak dipandang oleh mata dan tidak dapat diraba dengan indera yang manapun hanya dapat diraba dengan raba

\footnotetext{
${ }^{4}$ Starthof, Sadjarah Ngadegna Agama Djawa (ADS), Garut, 1979. hlm 1

${ }^{5}$ Prof. Kamil Kartapraja Op. cit. hlm 132
}

batin dan yakin. Dirumah Madrais selalu menyalakan api unggun.

3. Wajib menyembah kepada guru, ratu (pemerintah) dan kedua orang tua. Memelihara tanah dengan bercocok tanam dengan baik dan mengenai penghidupan, istilah menyembah tanah, mengkiblat ka ratu (artinya mentaati pemerintah)

4. Dilarang menentang adat desa, sedangkan agama Islam disebut agama yang baik untuk orang Arab.

5. Perkawinan, kematian dan sebagainya mempunyai cara sendiri di luar cara yang biasa dilakukan oleh umat Islam, dasar perkawinan suka-sama suka, pengikut Madrais dilarang kawin di penghulu. Untuk urusan cerai tidak ada, namun bila satu pasangan sudah tidak cocok satu sama lain mereka boleh berpisah begitu saja. Laki-laki kaum ADS dilarang untuk bersunat dan tidak boleh solat secara Islam, Soal warisan diatur berdasarkan hukum adat.

Untuk menghadapi kematian biasanya pengikut Madrais yang menghadapi sakarotul maut oleh kawan-kawannya ditunggu sambil dikatakan: wajon lawan, artinya ayo lawan, dan bila ia meninggal mereka berkata: Hih Bet olehan $=$ Lo, tukang kalah, prosesi pemakaman mereka dimasukkan dalam peti kaki dan tangan agak di lipat (mentongkrong), biasanya mayat akan di kuburkan terpisah dari kuburan kaum muslim.

\section{Istilah Keagamaan yang bermakna Filosofis dalam Ajaran Agama Djawa Sunda}

Ajaran ADS menjadikan ajaran asli Sunda sebagai pegangan hidup, ada tiga pedoman yang harus di pegang oleh penganut ADS dalam menjalankan kehidupannya yang dikenal dengan istilah Pikukuh Tilu yang terdiri dari:

1. Cara ciri manusia, cara ciri manusia ini teraplikasikan dalam dua hal yaitu :

a. Tatakrama: dimana setiap manusia harus tau bagaimana cara dia bersikap dan bertingkah laku yang baik menurut adat istiadatnya, ia menjelaskan kalau kami 
orang sunda, maka tata karma yang di pakai harus tata karma orang sunda.

b. Budi Pekerti: budi pekerti yang dimaksud adalah setiap perilaku harus dibarengi dengan amal perbuatan yang baik, karena perbuatan yang baik akan menghasilkan sikap dan penghargaan yang baik dimasyarakat dan perbuatan jahat akan berakibat pada sanksi sosial yang akan mengakibatkan pengucilan dan penghinaan dari masyarakat.

2. Cara ciri bangsa adalah ketika kita lahir di tanah Sunda maka kita harus teguh mempertahankan identitas kesundaan kita dengan berbahasa Sunda, berperilaku orang Sunda, rupa Sunda dengan slogan hidup "silih asah, silih asih dan silih asuh" yang di aplikasikan dalam bentuk cinta kasih, tata karma (aturan berperilaku), undak-usuk (etika bersikap), budi daya-daya budi (kreatifitas dan sopan santun berbahasa), wiwaha yuda na raga (sikap bijak dan penuh pertimbangan) seperti yang dianut dalam budaya masyarakat sunda.

Pikukuh tilu merupakan ajaran kuno suku sunda, istilah ini merupakan frase berbahasa sunda di lihat dari segi bahasa pikukuh tilu berasal dari dua kata, pikukuh dan tilu, pikukuh berarti yang bermakna suatu hal yang harus dipegang teguh karena sudah menjadi satu kepastian. Sedangkan kata tilu merupakan kata bilangan yang dalam bahasa Indonesia berarti tiga, jadi secara sederhana pikukuh tilu, bisa diartikan tiga hal yang harus senantiasa dipegang dalam kehidupan. ${ }^{6}$

Pikukuh tilu kalau diperluas maknanya diambil dari frase tri tangtu atau tangtu tilu, tangtu tilu, adalah sebuah pakem atau kitab ahlak budaya sebagai rujukan perilaku kehidupan baik secara pribadi ataupun sosial. Di bawah ini akan penulis paparkan maksud dari pikukuh tilu tersebut:

\section{Tri Tangtu Dina Raga (Salira)}

Konsep Tri tangtu dina raga, adalah pakem atau tuntunan yang menyangkut pribadi (ego)

\footnotetext{
${ }^{6}$ Yayasan Trimulya, Pikukuh Adat Karuhun Urang,pemaparan budaya spiritual, Cigugur Kuningan, 2000. hlm 16
}

sebagai manusia melalui konsep ini, manusia diberikan tuntutan untuk memahami dan mempertanyakan diri sendiri, mulai dari asal kemana akan tujuan hidup, oleh sebab itu tri tangtu dina raga mengingatkan kita pada halhal yang berkaitan dengan moralitas hidup atau akhlak budaya dan tuntutan hidup bermasyarakat. Aplikasi dari tri tangtu Dina raga dalam kehidupan sehari-hari adalah: ${ }^{7}$

1. Saur kudu dibubut (bercerita/ berbicara harus hati-hati dan harus pada tempat yang sesuai).

2. Basa kedah dihampelas (berbicara dengan baik dan sopan).

3. Gotong royong.

\section{Toleransi agama}

Selain istilah diatas di kenal juga istilah seperti Dzat, sifat, atma: sir, rasa, pikir: tekad, ucap, lampah: silih asah, silih asuh, silih asih: nyawa, raga, pakean, naluri, nurani, nalar. Istilah-istilah diatas adalah Rucita (tuntunan) berkehidupan.

\section{Tri Tangtu Di Buana}

Sedangkan untuk konsep tri tunggal buana adalah hukum yang mengatur kehidupan masing-masing individu dan kelompok di dalam suatu wilayah kekuasaan baik yang bersifat lokal (adat masyarakat setempat) atau mewakili daerah secara nasional. Dalam masyarakat kampung adat Cireunde, Cimahi yang mengadopsi spiritualitas ADS dikenal dua pantangan dalam bermasyarakat yaitu:

1. Jangan memakan keringat orang lain, ini berarti kita tidak boleh memakan hak orang lain seperti merampas, merampok, mencuri atau menyakiti orang lain.

2. Tidak boleh memaksa orang lain untuk menganut aliran kepercayaan yang mereka peluk.

Penulis berasumsi bahwa pada masyarakat kampung Cigugur Kuningan juga menerapkan hal yang sama seperti pada masyarakat Kampung Adat Cireunde karena salah satu pengikut setia Agama Djawa Sunda di Bandung terwakilkan pada Kampung Adat Cireunde, Cimahi, Bandung.

\footnotetext{
7 Wawancara bersama seorang pengikut ADS, bernama Budi pada tanggal 10 juni 2014.
} 


\section{Tri Tangtu Di Nagara}

Dalam dua wilayah kekuasaan yang mereka anut yaitu wilayah adat dan wilayah nasiona/luar adat itu terkadang menimbulkan hubungan yang berbeda hingga membentuk satu sistim sendiri dengan tetap berpedoman pada makna yang baik, benar dan buruk. Dalam ajaran ADS dikenal penggolangan staratifikasi kekuasaan terbagi pada tiga istilah Resi, Ratu dan Rama.

Resi adalah maha guru agama, adat dan yang menciptakan ajaran-ajaran. Ia berwenang sebagai pemilik kekuasaan tetapi tidak menjalankan kekuasaan. Sedangkan Ratu adalah yang menjalankan pemerintahan yang dikenal dengan raja, dan untuk Rama adalah rakyat yang menjalankan apa yang di perintahkan Resi dan Ratu. Pada Penganut ADS di Cigugur Kuningan di kenal ungkapan Rama Panyipta, Rama Pangwedar dan Rama panyusun.

Spiritualitas dalam tri tangtu di negara ini diaplikasikan dalam istilah sang seuweu karma (adab atau ahlak) yang mengajarkan bagaimana menata hubungan antapra pemimpin dan bawahannya, tata karma tersebut berpedomana pada dasa panta yang terdiri dari: ${ }^{8}$

1. Guna : Mengajarkan sesuatu harus di jelaskan kegunaannya baik oleh yang memerintah atau diperintah.

2. Ramah : Dalam memerintah harus disertai keramah tamahan.

3. Kagum : Perintah yang disampaikan harus sesuai dengan yang diperintah.

4. Pesok, Reureus : Artinya yang diperintah senang hati mengerjakan yang diperintahkan.

5. Asih : Suatu perintah harus didasarkan pada perasaan kasih sayang, sehingga suatu tugas akan dirasakan sebagai tanggung jawab bersama.

6. Karunya, sayang : Dengan penuh rasa saying perintah itu dapat dirasakan oleh yang melaksanakannya hingga timbul rasa

\footnotetext{
${ }^{8}$ Masyarakat Adat Karuhun Urang Sunda, pemaparan singkat: Jejak Sejarah Komunitas ADS ke Komunitas AKUR, Cigugur, Kuningan Jawa Barat, 2008
}

percaya diri dan tugas dapat dilaksanakan dengan sepenuh hati.

7. Makpruk : Dengan sikap dan kata-kata yang lembut yang diperintah tidak merasa dipaksa atau terpaksa.

8. Ngulas : Mengomentari hasil pekerjaan, jika pelu dikoreksi tetapi dengan cara bijaksana agar tidak menyinggung perasaan.

9. Ngecap : Menentramkan dengan cara menghargai hasil jeri payah orang lain.

Ngala angen: Yang memerintah harus dapat simpati dari yang memerintah sehingga yang memerintah akan selalu disegani dan dihormati.

\section{Cara Madrais Menyebarkan Ajarannya}

Wayang menjadi media yang ampuh dipakai oleh Madrais dalam menyebarkan ajarannya. Biasanya muridnya menonton dan Madrais menjadi dalangnya, selain wayang Madrais juga mengajarkan ajarannya melalui Tayuban atau tari-tarian. ${ }^{9}$ Nuansa hiburan dalam penyebaran ajaran ADS sangat di sukai oleh pengikutnya karena tingkat pendidikan dan pemahaman masyarakat Cigugur Kuningan pada saat itu masih rendah, maka melalui pertunjukan seni inti sari ajaran ADS mudah masuk dan diserap oleh pengikutnya ditambah pengetahuan dasar tentang ajaran Islam sangat lemah di antara mereka. Tiap bulan maulud murid-murid Madrais berkumpul di Cigugur, mereka datang dari Cirebon, Sumedang, Garut jumlahnya hampir 2500 orang. Pada waktu itu Madrais hanya dengan menggunakan cawat saja tiarap di atas api unggun, yang dinyalakan di dalam suatu dapur, sehingga Madrais dan api terhalang oleh tembok. Dari tubuh Madrais keluar keringat bercucuran yang ditampung dalam satu tempat yang penuh air, air campuran dengan keringat Madrais ini di bagi-bagikan kepada pengikutnya yang disambut sebagai berkah dari sang guru. ${ }^{10}$

Pengikut Madrais sangat berani berkorban untuk kepentingan gurunya. Pada zaman Belanda kehidupan Madrais beserta keluarga sangat mewah seperti seorang bupati. Madrais

\footnotetext{
${ }^{9}$ Prof.Kamil Kartapraja, Op. cit. hlm 133

10 Prof.Kamil Kartapraja, Ibid.hlm 133
} 
meninggal pada usia 65 tahun. Setelah kepergian pemimpin ADS digantikan oleh anaknya pangeran Teja Buana, tetapi pemahamannya tentang ajaran ADS tidak sebaik bapaknya dan cara dia menarik dana dari pengikutnyapun tidak sehalus ayahnya hingga banyak pengikutnya yang kecewa dan akhirnya berkurang.

Selama kepemimpinan Tejabuana aliran Madrais mengalami pasang surut, pada tahun 1944, Tejabuana mengumumkan ADS telah di bubarkan karena tekanan dari pihak Jepang, tetapi ketika pertengahan tahun 1948 ADS dihidupkan kembali oleh Tejabuana, karena yang berkuasa bukan Jepang lagi tetapi Belanda sampai waktu pemberontakan Kartosuwiryo menyerang kelompok ADS, maka Tejabuana pindah dari Cigugur dan tinggal di Cirebon. Pada tanggal 10 januari 1959 Tejabuana berusaha mengadakan Kongres Agama-agama Djawa dengan maksud untuk menghidupkan kembali ajaran ini, tetapi perkembangan ADS tidak pesat seperti dulu dan semakin hari semakin melemah.

Tejabuana mendaftarkan ADS pada badan koordinasi kebatinan Indonesia (BKKI), setelah himpunan kepercayaan terhadap tuhan yang maha esa (HPK) berdiri pada tahun 1981, pada perkembangan selanjutnya ADS memanifestasikan diri menjadi Paguyuban Adat Cara Karuhun Urang (PACKU) dibawah pimpinan Pangeran Djatikusuma dan terdaftar pada Direktorat Bina Hayat sebagai lembaga formal dengan No. 192/R.3/N.1/1982 yang bekerja di wilayah Jawa Barat dan sekitarnya. ${ }^{11}$

Akibat pendirian PACKU ini, mantan anggota dari ADS yang sudah bepindah ajaran menjadi Katolik sebanyak 2000 orang menyatakan keluar dari keanggotaan gereja dan berbalik arah menjadi anggota PACKU, banyak terjadi pertengkaran antara sesama anggota keluarga, bapak dengan anaknya, istri dengan suaminya dsb, setahun setelah kejadian tersebut PACKU kemudian dilarang dengan Surat Keputusan Kepala Kejaksaan Tinggi Jawa Barat Nomor: Kep. 44/K.2.3/8/82.

\footnotetext{
${ }^{11}$ Pemaparan Budaya Spiritual, Paguyuban Adat Cara Karuhun Urang, 1995, Cigugur-Kuningan Jawa Barat, hlm 14.
}

Sebagai akibat larangan tersebut, secara hukum status sekitar 2.000 orang penganut PACKU tersebut menjadi ilegal dan secara politik menjadi tidak benar (legally and politically incorrect). Menghadapi situasi tersebut, sebagian besar dari mereka segera kembali menjadi Katolik yang diterima kembali dengan penuh curiga, sebagian kecil masuk Islam, beberapa masuk Kristen Pasundan, sisanya termasuk Pangeran Djatikusumah beserta keluarganya tetap menyatakan diri secara resmi sebagai penghayat aliran kepercayaan.

\section{SIMPULAN}

Fenomena ADS ( Agama Djawa Sunda), adalah sebuah potret kebeagamaan pada masyarakat Indonesia Umumnya dan Jawa Barat. Khususnya yang menunjukkan bahwa agama pada suatu masyarakat harus mampu menunjukkan sifatnya baik sifat agama sebagai penjelas yang harus mampu memberikan makna keteraturan sosial di masyarakat dan pada kasus ADS ini sifat agama sebagai penjelas keteraturan sosial di masyarakat telah di rusak, karena ADS merupakan ajaran yang ingin mereformasi ajaran agama yang sudah mapan di masyarakat pada saat itu dengan menggabungkan antara ajaran Islam dan Sunda Wiwitan. Sedangkan sifat ke dua dari agama adalah sifat Normatif artinya agama harus mampu memberikan sistem makna yang bersifat menjadi legitimasi ${ }^{12}$. Dan dalam kasus ADS ini, Madrais sebagai satu sosok yang dianggap dapat memberikan legitimasi dan harapan yang dibutuhkan oleh masyarakat pada waktu itu hingga ADS ini pengikutnya banyak dan menyebar di beberapa wilayah di Jawa Jarat, tapi setelah kematian dari Madrais, ADS mulai surut dan tenggelam karena penerus Madrais yaitu anaknya sendiri Tejabuana, tidak mampu memberikan legitimasi yang baik pada pengikutnya.

\footnotetext{
12 legitimasi adalah segala macam bentuk penjelasan yang diberikan untuk membenarkan sebuah tindakan ,perilaku atau praktek-praktek yang ada dalam masyarakat.
} 


\section{DAFTAR PUSTAKA}

Djatikusuma, (pengantar), Pemaparan Budaya Spiritual Paguyuban Adat Cara Karuhun Urang, Cigugur 1995.

Hamka, Perkembangan Kebatinan di Indonesia, Bulan bintang, Jakarta, 1976.

Kartapraja, Kamil, Aliran Kebatinan Dan Kepercayaan Di Indonesia, CV Haji Masagung, Jakarta, 1990.

Majalah Tempo, Terbitan 29 Januari 1983.

Masyarakat Adat Karuhun Urang Sunda, pemaparan singkat: Jejak Sejarah Komunitas ADS ke Komunitas AKUR, Cigugur, Kuningan Jawa Barat, 2008.
Munandar, Agus Aris, Tatar Sunda Masa Silam, Wedata Tama Widyasastra, Jakarta, 2010.

Rozak, Abdul, Teologi Kebatinan Sunda, Kiblat, Bandung, 2005.

Starthof, Sadjarah Ngadegna Agama Djawa (ADS), Garut, 1979.

Wikipedia, "Cigugur, Kuningan”, 2016, http://id.wikipedia.org/wiki/Cigugur,_Kuni ngan\#Batas-batas_Wilayah

Yayasan Trimulya, Pikukuh Adat Karuhun Urang, Pemaparan Budaya Spiritual, Cigugur Kuningan, 2000. 